\title{
Blood transfusion, colloid therapy and the possible saving of albumin volumes during surgery: data analysis of the survey for certified hospitals of the Japanese Society of Anesthesiologists
}

\author{
Hideki Miyao $^{1} \cdot$ Safety Committee of Japanese Society of Anesthesiologists ${ }^{2}$
}

Received: 19 November 2015 / Accepted: 28 December 2015 / Published online: 14 January 2016

(C) The Author(s) 2016. This article is published with open access at Springerlink.com

\begin{abstract}
Purpose Third-generation hydroxyethyl starch (HES) 130/0.4 has a larger dose limitation (up to $50 \mathrm{~mL} / \mathrm{kg} / \mathrm{day}$ ) than HES 70/0.5 (up to $1000 \mathrm{~mL} /$ day) which has been used in Japan for 40 years. The aim of this study was to survey the current intraoperative blood transfusion and volume therapy and to predict the possible reduction of intraoperative albumin consumption assuming further replacement by HES 130/0.4 using data obtained from a survey by the Japanese Society of Anesthesiologists (JSA), although HES130/0.4 was not launched in Japan during this survey period.

Methods In a JSA survey conducted at JSA-certified hospitals, 12,856 patients with a certain amount of blood loss were analyzed for 1 month (April, 2012). The patients were divided into two groups-group A included patients aged $\geq 11$ years and group $\mathrm{B}$ included patients aged $<10$ years. The possible lower volume of intraoperative albumin was calculated assuming that HES $130 / 0.4$ was used up to a dose of $50 \mathrm{~mL} / \mathrm{kg}$.

Results Blood loss (total 15,111 L; 15,057 L in group A and $54 \mathrm{~L}$ in group B) was treated with allogeneic transfusion (total $7970 \mathrm{~L} ; 7893 \mathrm{~L}$ in group A and $77 \mathrm{~L}$ in group B) and auto-transfusion (total $1777 \mathrm{~L} ; 1771 \mathrm{~L}$ in group A and $6 \mathrm{~L}$ in group $\mathrm{B})$ in both groups $(n=11,670$ and 119$)$. Albumin (total $1391 \mathrm{~L} ; 1376 \mathrm{~L}$ in group A and $15 \mathrm{~L}$ in
\end{abstract}

Hideki Miyao

miyaoh@saitama-med.ac.jp

1 Department of Anesthesiology, Saitama Medical Center, Saitama Medical University, 1981, Kamoda, Kawagoe, Saitama 350-8550, Japan

2 Japanese Society of Anesthesiologists, 1-5-2, Minami-cho, Minatojima, Chuo-ku, Kobe 650-0047, Japan group B), and HES 70/0.5 (total $7645 \mathrm{~L} ; 7638 \mathrm{~L}$ in group A and $7 \mathrm{~L}$ in group $\mathrm{B}$ ) were used in both groups $(n=10,850$ and 116). Five percent and $4.4 \%$ albumin (total $1189 \mathrm{~L}$; $1180 \mathrm{~L}$ in group $\mathrm{A}$ and $9 \mathrm{~L}$ in group B) could be replaced by HES 130/0.4 if HES 130/0.4 had been used up to a dose of $50 \mathrm{~mL} / \mathrm{kg}$.

Conclusion Blood loss $(15,111$ L) was replaced with allogeneic transfusion (53\%), auto-transfusion (12\%), albumin $(9 \%)$ and HES 70/0.5 (51\%) during surgery in April 2012. The predicted volume of 5 and $4.4 \%$ albumin saved during this 1-month period if HES 130/0.4 had been used up to a dose of $50 \mathrm{~mL} / \mathrm{kg}$ was $1189 \mathrm{~L}$ ( $86 \%$ of actual amount used).

Keywords Transfusion · Volume therapy $\cdot$ Hydroxyethyl starch · Albumin

\section{Introduction}

Perioperative fluid therapy has shifted from the liberal use of crystalloids to goal-directed volume-restricted therapy using colloids for blood loss substitution [1-3]. In Japan, hydroxyethyl starch (HES) is the preferred colloid during surgery with HES 70/0.5 (Hespander ${ }^{\circledR} /$ Salinhes $^{\circledR}$ ) being the only HES specification available for the past 40 years. The maximum daily dosage of HES 70/0.5 has been limited to $1000 \mathrm{~mL}$. When a higher volume of a colloid solution was indicated, albumin had to be used instead of HES 70/0.5 because new generation of HES had not been available in Japan, resulting in increased consumption of intraoperative albumin. Third-generation HES 130/0.4 (Voluven ${ }^{\circledR}$ ) has a higher dose limitation $(50 \mathrm{~mL} / \mathrm{kg} /$ day $)$ than HES 70/0.5 and was launched in Japan in October 2013. 


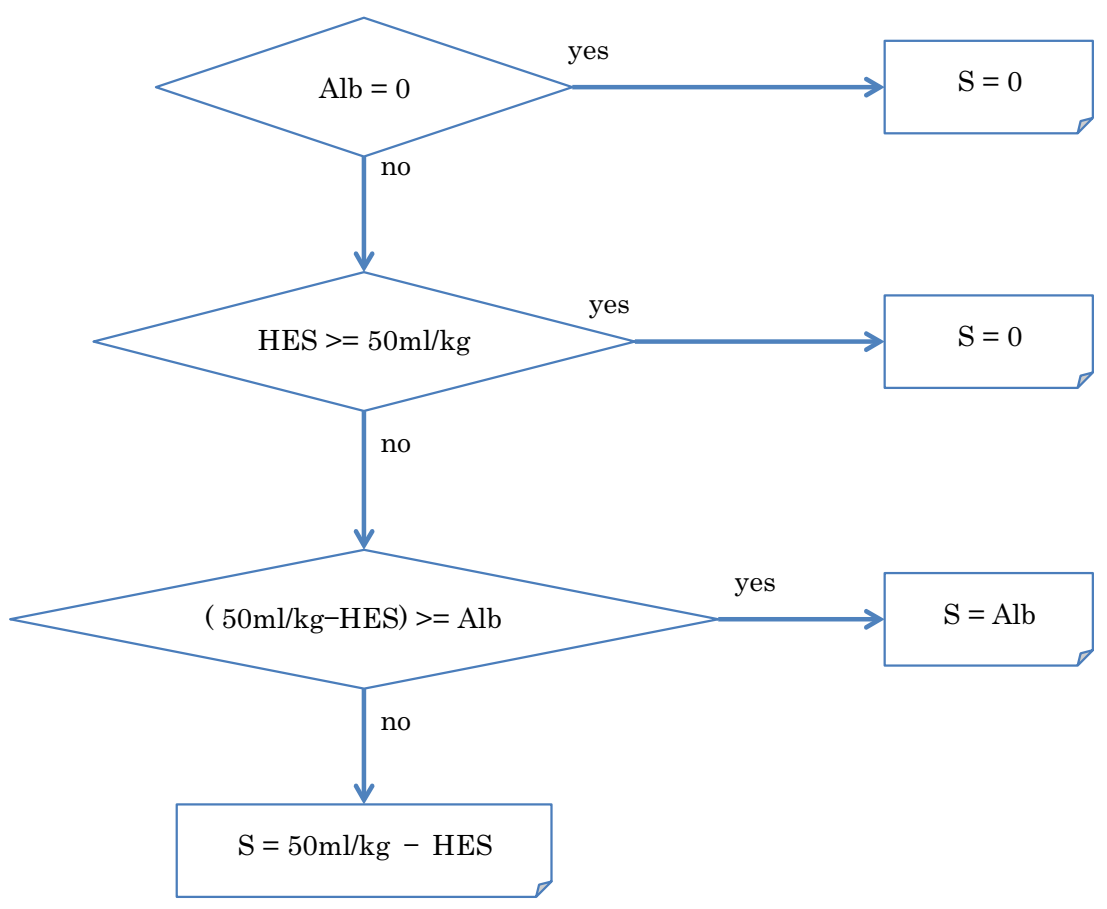

Fig. 1 Algorithm for calculation of possible saving of albumin if $6 \% \mathrm{HES} \mathrm{130/0.4} \mathrm{had} \mathrm{been} \mathrm{used} \mathrm{up} \mathrm{to} \mathrm{a} \mathrm{total} \mathrm{dose} \mathrm{of} 50 \mathrm{~mL} / \mathrm{kg}$ instead of albumin. Alb intraoperative infusion volume of 5 or $4.4 \%$ albumin, HES $6 \%$ HES 70/0.5, $S$ saving volume of albumin. Example: If body weight is $60 \mathrm{~kg}$ and $5 \%$ albumin $(1500 \mathrm{~mL})$ would be used, 1st branch of upper Fig. 1 is "no". If HES $(1000 \mathrm{~mL})$ would be used, the $2 \mathrm{nd}$ branch is "no" because HES $(1000 \mathrm{~mL})$ is smaller than $50 \mathrm{~mL} / \mathrm{kg}(3000 \mathrm{~mL} / 60 \mathrm{~kg})$. The $3 \mathrm{rd}$ branch is "yes" because 50 $\mathrm{mL} / \mathrm{kg}(3000 \mathrm{~mL})$ - HES $1000 \mathrm{~mL}=2000 \mathrm{~mL}$ which is larger than albumin used $(1500 \mathrm{~mL})$. This means that HES 130/0.4 could be used

In July 2012, 1 year prior to the launch of HES 130/0.4, the Japanese Society of Anesthesiologists (JSA) initiated a survey for usage of albumin and HES 70/0.5 within JSAcertified hospitals to document intraoperative infusion and transfusion therapy including colloid therapy (HES, albu$\mathrm{min}$, and others). The aim of this study was to investigate the current status of blood transfusion and colloid therapy in operating theaters in Japan and to predict the possible reduction of intraoperative albumin volumes assuming that colloid volumes up to $50 \mathrm{~mL} / \mathrm{kg}$ could be replaced by HES 130/0.4.

\section{Methods}

After approval by the ethics committee of the JSA, questionnaires prepared by the Safety Committee of the JSA were sent to 1234 JSA-certified hospitals in 2012. The survey consisted of two parts. In the first part, the representatives of anesthesiologists at individual hospitals were asked to complete a questionnaire on the use of $6 \%$ HES 70/0.5 up to $3000 \mathrm{~mL}$ and this amount is larger than HES 70/0.5 (1000 mL) plus albumin $(1500 \mathrm{~mL})$ used. Then, $1500 \mathrm{~mL}$ of albumin used could be replaced with HES 130/0.4, consequently saving volume of albumin is whole amount of albumin used $(1500 \mathrm{~mL})$. If $5 \%$ albumin $(2500 \mathrm{~mL})$ would be used in the upper example, the 3rd branch is "no" because $50 \mathrm{~mL} / \mathrm{kg}(3000 \mathrm{~mL})$ - HES $1000 \mathrm{~mL}=2000 \mathrm{~mL}$ which is smaller than albumin used $(2500 \mathrm{~mL})$. Then, $50 \mathrm{~mL} / \mathrm{kg}$ $(3000 \mathrm{~mL}$ )-HES $1000 \mathrm{~mL}=2000 \mathrm{~mL}$ which is $80 \%$ of albumin used $(2500 \mathrm{~mL})$ is the saving volume of albumin

and albumin in the operating theater. In the second part, data describing transfusion and infusion status of surgical patients with intraoperative blood loss of either $\geq 500 \mathrm{~mL}$ for patients aged $\geq 11$ years (group A) or with intraoperative blood loss $\geq 10 \mathrm{~mL} / \mathrm{kg}$ for patients aged $<10$ years (group B) was derived from a 1-month database (April 2012).

The database from the second part of the JSA survey 2012 was the subject of the present study. The results of the first part will be presented soon on the official home page of JSA.

Unknown blood loss from certain procedures such as cardiac surgery with cardio-pulmonary bypass and abdominal aortic aneurysm surgery with intraoperative autologous blood salvage was not counted in the analysis of blood loss. Blood loss reported including amniotic fluid in Caesarian section or ascites in abdominal surgery was adopted to the blood loss as they were. The amount of transfusion was documented in $\mathrm{mL}$, but when units were used, it was calculated as $140 \mathrm{~mL}$ per unit of red blood cells or $120 \mathrm{~mL}$ per unit of fresh frozen plasma in a standardized way. Platelet 
Surgery in April 2012 reported by 707 JSA certified hospitals $n=134,500$

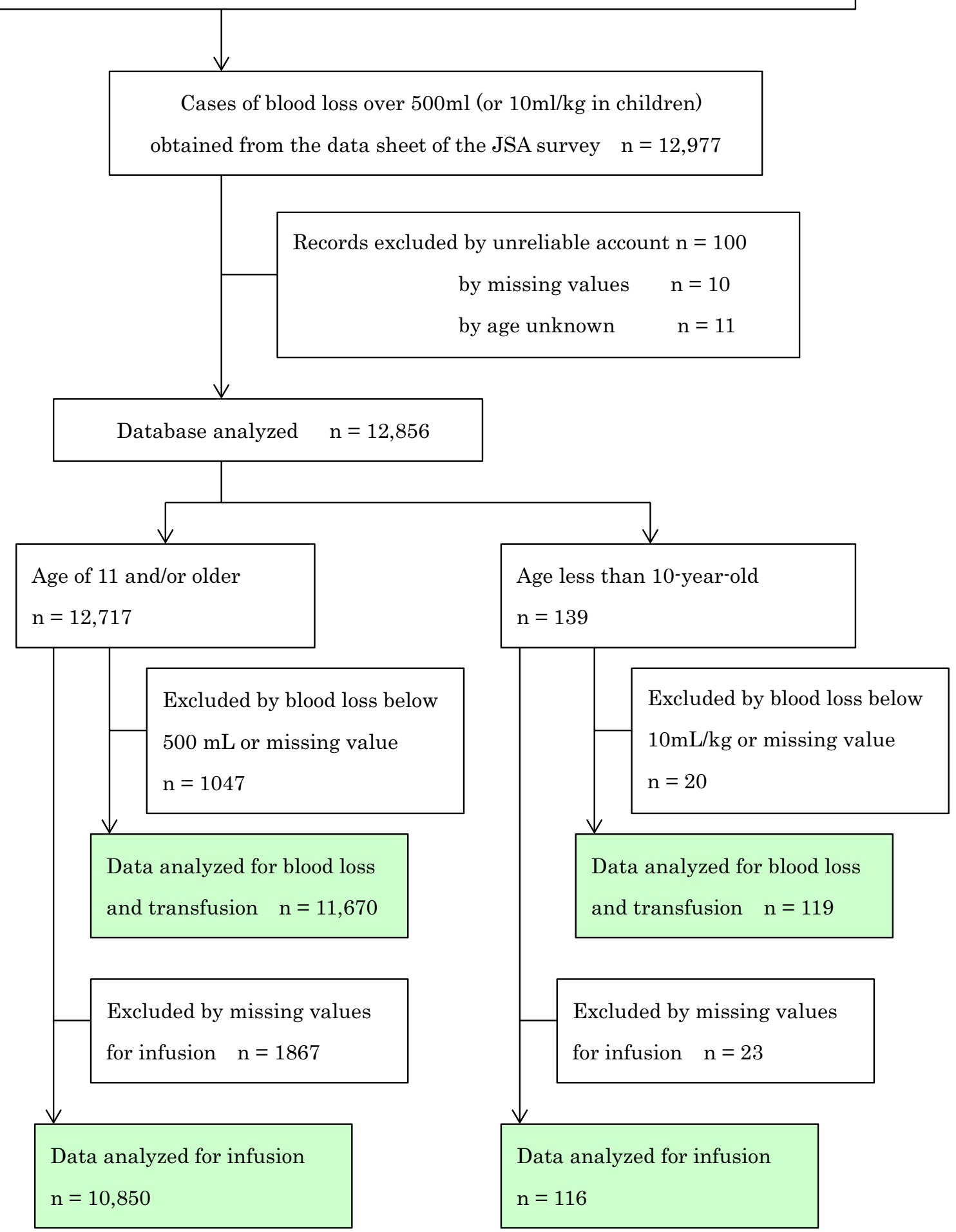

Fig. 2 Diagram for data selection

transfusion was excluded from further analysis as the documentation could not be clarified (units or $\mathrm{mL}$ ) in many cases.
The algorithm to calculate the volume of 5 and $4.4 \%$ albumin that could have been saved if $6 \%$ HES 130/0.4 was used up to a dose of $50 \mathrm{~mL} / \mathrm{kg}$ is given in Fig. 1. The 
intraoperative infusion volumes of 20 and $25 \%$ albumin were excluded from the above calculations because these solutions were mostly used in the priming solution of cardiopulmonary bypass circuit.

\section{Statistics}

All variables were analyzed by descriptive statistical analysis.

\section{Results}

Seven hundred and seven of 1234 JSA-certified hospitals returned valid questionnaires for analysis and reported 134,500 surgical patients of whom 12,977 matched the methodology of this survey. Finally 11,670 patients were suitable for analysis for blood loss/transfusion,

Table 1 Demographic data in each group

\begin{tabular}{lll}
\hline & Group A & Group B \\
\hline $\begin{array}{l}\text { Age (years) } \\
\text { Valid cases }\end{array}$ & 11,670 cases & 119 cases \\
$\quad \begin{array}{l}\text { Mean (median: min- } \\
\quad \text { max) }\end{array}$ & \\
$\begin{array}{l}\text { Body weight (kg) } \\
\text { Valid cases }\end{array}$ & 11,446 cases & 119 cases \\
$\begin{array}{l}\text { Mean (median: } \text { min- }- \\
\quad 60.2 \mathrm{~kg}(59.6:\end{array}$ & $9.7 \mathrm{~kg}(7.7: 1.7-36.1)$ \\
$\quad$ max) & $30.1-138.7)$ & \\
\hline
\end{tabular}

min minimum, max maximum with 10,850 patients being suitable for infusion therapy in group A, and 119 patients being suitable for blood loss/transfusion and 116 for infusion therapy in group B (Fig. 2).

Table 1 shows demographic data in groups A and B. Table 2 shows blood loss, allogeneic transfusion, and autotransfusion of patients in groups A and B. Total blood loss in group A $(15,057 \mathrm{~L})$ was treated with allogeneic transfusion (7893 L: $52 \%$ of total blood loss) and auto-transfusion (1771 L:12 \% of total blood loss), whereas total blood loss in group B $(54,461 \mathrm{~mL})$ was treated with allogeneic transfusion (77,016 mL: $141 \%$ of total blood loss) and auto-transfusion (6338 mL: $12 \%$ of total blood loss) . It was evident that transfusion therapy dominates in pediatric patients.

Table 3 shows the total infusion volume including crystalloids, colloids, and predicted volume of albumin saved in groups A and B. Of 10,850 patients in group A, 1979 $(18 \%)$ were given albumin $(5,4.4,20$, or $25 \%)$, and 8464 (78 \%) were given HES 70/0.5. Of 8464 patients given HES 70/0.5, 1518 (18\%) were given $>1000 \mathrm{~mL}$ HES $70 / 0.5$ (this is the limitation volume specified in the package insert). One thousand one hundred eighty liters amount of 5 and $4.4 \%$ albumin, which was $86 \%$ of actually amount used (1366.2 L), could be replaced by HES 130/0.4 if HES 130/0.4 had been used up to a dose of $50 \mathrm{~mL} / \mathrm{kg}$. Of 116 patients in group B, $76(66 \%)$ were given albumin $(5,20$, or $25 \%)$, and $45(39 \%)$ were given HES 70/0.5. It became evident that the rate of albumin given was higher and the rate of HES given was lower in pediatric patients (group B) than those in group A. Nine thousand one hundred seventy four $\mathrm{mL}$ amout of $5 \%$ albumin, which was 68 $\%$ of actually amount used $(13,446 \mathrm{~mL})$, could be replaced
Table 2 Blood loss, allogeneic transfusion, and autotransfusion

\begin{tabular}{lll}
\hline & Group A & Group B \\
\hline Blood loss & & \\
Valid cases & 11,670 cases & 119 cases \\
Total amount & $15,057 \mathrm{~L}$ & $54,461 \mathrm{~mL}$ \\
Mean (median: min-max) & $1292 \mathrm{~mL}(911: 500-44,950)$ & $458 \mathrm{~mL}(59)$ [300 (37): 17 (10)-2890 (389)] \\
Allogeneic transfusion & & \\
Valid cases & 5634 cases & 104 cases \\
Total amount & $7893 \mathrm{~L}$ & $77,016 \mathrm{~mL}$ \\
Mean (median: min-max) & $1401 \mathrm{~mL}(800: 1-48,300)$ & $741 \mathrm{~mL}(367: 27-5958)$ \\
Auto-transfusion & & \\
Valid cases & 2624 cases & 32 cases \\
Total amount & $1771 \mathrm{~L}$ & $6338 \mathrm{~mL}$ \\
Mean (median: min-max) & $675 \mathrm{~mL}(500: 1-15,500)$ & $198 \mathrm{~mL}(148: 4-1030)$ \\
\hline
\end{tabular}

Valid cases of blood loss indicates blood loss $\geq 500 \mathrm{~mL}$ in group A and $10 \mathrm{~mL} / \mathrm{kg}$ in group B. Valid cases of allogeneic and auto transfusion indicates over $0 \mathrm{~mL}$. Allogeneic transfusion included red blood cell concentrate and fresh frozen plasma but not platelet concentrate. Auto-transfusion included preoperative donated autologous transfusion, intraoperative hemodilution autologous transfusion, and intraoperative blood cell salvage transfusion, $\min$ minimum; $\max$ maximum, () in group B: values in $\mathrm{mL} / \mathrm{kg}$ 
Table 3 Total infusion volume, colloids volume, and predicted volume of albumin saved

\begin{tabular}{|c|c|c|}
\hline & Group A & Group B \\
\hline \multicolumn{3}{|l|}{ Total infusion volume } \\
\hline Valid cases & 10,850 case & 116 cases \\
\hline Total amount & $32,283.3 \mathrm{~L}$ & $87,431 \mathrm{~mL}$ \\
\hline Mean (median: min-max) & $2975 \mathrm{~mL}(2500: 50-42,940)$ & 754 mL (361: 17-6940) \\
\hline \multicolumn{3}{|l|}{$5 \%$ albumin } \\
\hline Valid cases & 1751 cases & 53 cases \\
\hline Total amount & $1280.0 \mathrm{~L}$ & $13,446 \mathrm{~mL}$ \\
\hline Mean (median: min-max) & 731 mL (500: 4-9500) & $254 \mathrm{~mL}(110: 20-1650)$ \\
\hline \multicolumn{3}{|l|}{$4.4 \%$ albumin } \\
\hline Valid cases & 133 cases & 0 case \\
\hline Total amount & $86.2 \mathrm{~L}$ & - \\
\hline Mean (median: min-max) & 648 mL (500: 100-3500) & - \\
\hline \multicolumn{3}{|l|}{$20 \%$ albumin } \\
\hline Valid cases & 15 cases & 2 cases \\
\hline Total amount & $2.5 \mathrm{~L}$ & $16 \mathrm{~mL}$ \\
\hline Mean (median: min-max) & 163 mL (100: 50-1000) & $8 \mathrm{~mL}(8: 8-8)$ \\
\hline \multicolumn{3}{|l|}{$25 \%$ albumin } \\
\hline Valid cases & 80 cases & 21 cases \\
\hline Total amount & $7.0 \mathrm{~L}$ & $1640 \mathrm{~mL}$ \\
\hline Mean (median: $\min -\max )$ & $88 \mathrm{~mL}$ (100: 30-250) & $78 \mathrm{~mL}$ (80: 50-130) \\
\hline \multicolumn{3}{|l|}{ HES70/0.5 } \\
\hline Valid cases & 8464 cases & 45 cases \\
\hline Total amount & $7637.5 \mathrm{~L}$ & $7131 \mathrm{~mL}$ \\
\hline Mean (median: $\min -\max )$ & 902 mL (,000: 10-12,500) & 159 (12) mL [62 (8): $10(1)-1000(61)]$ \\
\hline \multicolumn{3}{|l|}{ Other artificial colloids } \\
\hline Valid cases & 295 cases & 0 case \\
\hline Total amount & $195.5 \mathrm{~L}$ & - \\
\hline Mean (median: $\min -\max )$ & 663 mL (500: 50-2000) & - \\
\hline \multicolumn{3}{|l|}{ Albumin saved by HES130/0.4 } \\
\hline Valid cases & 1817 cases & 52 cases \\
\hline Total amount & $1180.1 \mathrm{~L}$ & $9174 \mathrm{~mL}$ \\
\hline Mean (median: min-max) & $650 \mathrm{~mL}(500: 4-3350)$ & 176 mL (100: 20-905) \\
\hline
\end{tabular}

Total infusion volume included crystalloids and colloids. Other artificial colloid was only dextran. 20 and $25 \%$ albumin were ineligible for analysis of "Albumin saved by HES 130/0.4"; min minimum, max maximum, () in group B: values in $\mathrm{mL} / \mathrm{kg}$ by HES 130/0.4 if HES 130/0.4 had been used up to a dose of $50 \mathrm{~mL} / \mathrm{kg}$.

The calculation of the total predicted volume of albumin saved for 5 and $4.4 \%$ albumin in groups $\mathrm{A}$ and $\mathrm{B}$ was $1189 \mathrm{~L}$ in April 2012. This predicted volume of albumin saved $(1189 \mathrm{~L})$ corresponds to $86.2 \%$ of actual amount of 4.4 and $5 \%$ albumin $(1379 \mathrm{~L})$ used during this period.

The JSA survey 2012 revealed that $15,111 \mathrm{~L}$ of blood loss were replaced with $7970 \mathrm{~L}$ of allogeneic transfusion, $1777 \mathrm{~L}$ of auto-transfusion, $1391 \mathrm{~L}$ of albumin, and $7645 \mathrm{~L}$ of HES 70/0.5 during surgery in April 2012. The predicted volume of 5 and $4.4 \%$ albumin saved was $1189 \mathrm{~L}$ which was $86 \%$ of actual amount used during this 1-month period if HES 130/0.4 had been used up to a dose of $50 \mathrm{~mL} / \mathrm{kg}$.

\section{Discussion}

The present survey is a unique study of a large database obtained from 707 JSA-certified hospitals to describe the current blood loss/transfusion and colloid therapy during surgery in Japan. The results of this survey may lead to a new strategy for intraoperative volume therapy.

HES has been used for perioperative volume replacement as a plasma substitute in operating theaters and intensive care units. We should consider two aspects for perioperative use of HES. First, HES can reduce intraoperative fluid loading. Recent intraoperative fluid management has changed from the liberal infusion strategy of extracellular fluid to a relatively goal-directed volume-restricted 
strategy using HES. Lowell et al. demonstrated that weight gain from fluid overloading during surgery correlated to high mortality rates [4]. Enhanced recovery after surgery consensus guideline $[5,6]$ specified "Intraoperative fluids should be balanced to avoid both hypo- and hypervolemia. Intraoperative goal directed fluid therapy should be considered on an individual basis". In surgical use, HES (especially third-generation HES 130/0.4) demonstrated good outcomes for transfusion rate [7], mortality [8], and renal function [7]. HES still plays a major role in goal-directed intraoperative fluid therapy.

Second, HES 130/0.4 can reduce intraoperative albumin consumption because higher doses can be given compared to HES 70/0.5. Japan has not only been criticized for large albumin consumption, but also for high cost excessive perioperative albumin usage. The present study focused on this second issue.

The present study represents a large sample of 123,500 surgical patients with 10,966 patients (10,850 patients in group A and 116 patients in group B) being suitable for analysis.

Approximately $64 \%$ of blood loss was replaced by allogeneic (52\%) and auto-transfusion (12\%). In group $\mathrm{A}$, the auto-transfusion rate was $30 \%$ of all transfusions, which was thought to be very high; however, in group B, $141 \%$ of blood loss was replaced by allogeneic transfusion. There are two possible reasons. One reason is that a small volume of blood loss leads to hypovolemia and an unstable hemodynamic state in small children. In such situations, anesthesiologists tend to decide on early transfusion. Another reason is that the smaller the blood loss, the higher the difference between the actual blood loss and the measured blood loss because of drying gauze with the blood to be measured, and immeasurable blood absorbed by cover sheets or spilt on the floor. Anesthesiologists then tend to assess the volume status based on estimated blood loss rather than measured blood loss by the nurse.

The predicted volume of 5 and $4.4 \%$ albumin saved was $1189 \mathrm{~L}$ in 1 month. This would amount to approximately 14,300 L over 1 year. Based on the statistics from the Ministry of Health, Labor and Welfare 2012 (http://www.mhlw.go.jp/ $\mathrm{stf} /$ shingi/2r9852000002hs9l.html), the total number of surgeries performed in 1648 diagnosis procedure combination (DPC) hospitals during a 6-month period was $2,045,932$, which is 2.8 times higher than the source of the present study $(123,500$ in 1 month). Approximately 40,000 L $(14,300 \mathrm{~L} \times 2.8)$ of albumin would be saved in a year. The consumption of albumin in Japan in 2009 was 1460,000 L (http://www.mhlw.go.jp/newinfo/kobetu/iyaku/kenketsugo/2q/pdf/5-2.pdf). As a result of this analysis, $2.7 \%(40,000 / 1,460,000)$ of total albumin consumption could be saved in operating theaters.

The principle proof of this analysis was recently supported by a pilot study [8] as well by a study of surgical patients [9]. Blood loss and transfusion requirements in cardiac surgery were higher for albumin compared to HES 130/0.4 [10]. Albumin administration in cardiac surgery was associated with a dose-dependent risk of acute kidney injury, whereas $6 \%$ HES 130/0.4 was not [11]. Albumin administration for critically ill patients did not improve mortality or morbidity even for hypoalbuminemia patients [12]. Based on these findings, third-generation HES 130/0.4 may become a major colloid for perioperative volume therapy instead of albumin. In cases of massive administration of HES 130/0.4 and also of albumin, however, dilutional coagulopathy should be monitored and treated appropriately with fresh frozen plasma and platelet concentrate.

\section{Limitation of the study}

1. As anesthesiologists may not use up to the maximum dose of HES 130/0.4 in cases of bleeding during surgery, the calculation of the possible volume of saved albumin may be overestimated.

2. The intraoperative infusion volume of 20 and $25 \%$ albumin was excluded from the possible saving volume of albumin as it was mostly used in the priming solution of cardiopulmonary bypass circuit. This albumin, however, could also be replaced by HES 130/0.4 as the colloid for priming solution.

\section{Conclusion}

Based on data from the 2012 JSA survey, 15,111 L of blood loss were replaced with $7970 \mathrm{~L}$ of allogeneic transfusion, $1777 \mathrm{~L}$ of auto-transfusion, $1391 \mathrm{~L}$ of albumin, and $7645 \mathrm{~L}$ of HES 70/0.5 during surgery in April 2012. The predicted volume of 5 and $4.4 \%$ albumin saved was $1189 \mathrm{~L}(86 \%$ of actual amount used) during this 1-month period if HES $130 / 0.4$ had been used up to a dose of $50 \mathrm{~mL} / \mathrm{kg}$.

Open Access This article is distributed under the terms of the Creative Commons Attribution 4.0 International License (http://creativecommons.org/licenses/by/4.0/), which permits unrestricted use, distribution, and reproduction in any medium, provided you give appropriate credit to the original author(s) and the source, provide a link to the Creative Commons license, and indicate if changes were made.

\section{References}

1. Gan TJ, Soppitt A, Maroof M, El-Moalem H, Robertson KM, Moretti E, Dwane P, Glass PS. Goal-directed intraoperative fluid administration reduces length of hospital stay after major surgery. Anesthesiology. 2002;97(4):820-6.

2. Nisanevich V, Felsenstein I, Almogy G, Weissman C, Einav S, Matot I. Effect of intraoperative fluid management on outcome after intraabdominal surgery. Anesthesiology. 2005;103(1):25-32. 
3. Ghneim MH, Regner JL, Jupiter DC, Kang F, Bonner GL, Bready MS, Frazee R, Ciceri D, Davis ML. Goal directed fluid resuscitation decreases time for lactate clearance and facilitates early fascial closure in damage control surgery. Am J Surg. 2013;206(6):995-9 (discussion 999-1000).

4. Lowell J, Schifferdecker C, Driscoll D, Benotti P, Bistrian B. Postoperative fluid overload: not benign problem. Crit Care Med. 1990;18:728-33.

5. Fearon $\mathrm{KCH}$, Ljungqvist $\mathrm{O}$, Von Meyenfeldt $\mathrm{M}$, Revhaug $\mathrm{A}$, Dejong CHC, Lassen K, Nygren J, Hause J, Soop M, Andersen J, Kehlet H. Enhanced recovery after surgery: a consensus review of clinical care for patients undergoing colonic resection. Clin Nutr. 2005;24(3):466-77.

6. Varadhan KK, Neal KR, Dejong CHC, Fearon KCH, Ljungqvist O, Lobo DN. The enhanced recovery after surgery (ERAS) pathway for patients undergoing major elective open colorectal surgery: a meta-analysis of randomized controlled trials. Clin Nutr. 2010;29(4):434-40.

7. James MF, Michell WL, Joubert IA, Nicol AJ, Navsaria PH, Gillespie RS. Resuscitation with hydroxyethyl starch improves renal function and lactate clearance in penetrating trauma in a randomized controlled study: the FIRST trial (fluids in resuscitation of severe trauma). Br J Anaesth. 2011;107(5):693-702.

8. Morioka N, Ozaki M, Yamakage M, Morimatsu H, Suzuki Y, Bepperling F, Miyao H, Namiki A, Morita K. The volume effect and safety of $6 \%$ hydroxyethyl starch 130/0. 4 in patients undergoing major elective surgery: an uncontrolled, open-labeled, multi-center study. Open J Anesthesiol. 2013;3:326-37.

9. Van Der Linden P, James M, Mythen M, Weiskopf RB. Safety of modern starches used during surgery. Anesth Analg. 2013;116(1):35-48.

10. Jacob M, Fellahi J, Chappell D, Kurz A. The impact of hydroxyethyl starches in cardiac surgery-a meta-analysis. Crit Care. 2014;18:656.

11. Frenette AJ, Bouchard J, Bernier P, Charbonneau A, Nguyen LT, Rioux JP, Troyanov S, Williamson DR. Albumin administration is associated with acute kidney injury in cardiac surgery : a propensity score analysis. Crit Care. 2014;18(6):602.

12. Roberts I, Blackhall K, Alderson P, Bunn F, Schierhout G. Human albumin solution for resuscitation and volume expansion in critically ill patients. Cochrane Database Syst Rev. 2011;11:CD001208. 